\title{
Penerapan teknik cynema therapy untuk meningkatkan pemahaman siswa terhadap bahaya merokok
}

\author{
Muhammad Fatchurahman \\ Study Program : Guidance and Counseling University of Muhammadiyah Palangkaraya \\ Email: mfatchurahman789@gmail.com
}

(Diterima: 06-Maret-2017; di revisi: 06-Mei-2017; dipublikasikan: 20-Juni-2017)

\begin{abstract}
The purpose of the study is to know the application of cinema therapy techniques that can improve students' understanding to the dangers of smoking at SMP Muhammadiyah Palangkaraya. This research is a quantitative experimental approach. Experimental design used in this study was pre-experimental design in the form of one group pretest-posttest design. This means that by this study design uses only one group as the experimental group was given treatment without a comparison group. The population of this study amounted 28 people, with 8 samples indicated the learners who have an understanding to dangers of smoking are low. The collection of research data using interviews, documentation, questionnaires and focus group focus. Analysis of data using statistical test of Paired Samples $\mathrm{T}$ Test with application software SPSS version 17.00. The results showed that the cinema therapy techniques can improve students' understanding to the dangers of smoking at SMP Muhammadiyah Palangkaraya.
\end{abstract}

Keyword: Cinema Therapy Techniques, Dangers of Smoking

\begin{abstract}
Abstrak: Tujuan dari penelitian ini untuk mengetahui penerapan teknik cynema therapy mampu dapat meningkatkan pemahaman siswa terhadap bahaya merokok pada SMP Muhammadiyah Palangkaraya. Penelitian ini merupakan penelitian kuantitatif dengan pendekatan eksperimen. Desain eksperimen yang digunakan dalam penelitian ini adalah pre-experimental design dalam bentuk one group pretest-posttest design. Artinya dengan desain penelitian ini hanya menggunakan satu kelompok sebagai kelompok eksperimen yang diberikan perlakuan tanpa adanya kelompok pembanding. Populasi dalam penelitian ini berjumlah 28 orang, dengan sampel 8 orang peserta didik yang terindikasi memiliki pemahaman terhadap bahaya merokok yang rendah. Pengumpulan data penelitian menggunakan wawancara, dokumentasi, angket dan focuss group discussion. Analisis data menggunakan uji statistik Paired Samples T Test dengan aplikasi software SPSS versi 17.00. Hasil penelitian menunjukkan bahwa teknik cynema therapy mampu meningkatkan pemahaman siswa terhadap bahaya merokok pada SMP Muhammadiyah Palangkaraya.
\end{abstract}

Kata kunci: Teknik Cynema Therapy, Bahaya Merokok

Copyright (C 2017 Universitas Negeri Makassar.. This is an open access article under the CC BYNC-ND license (http://creativecommons.org/licenses/by-nc-nd/4.0/).

\section{PENDAHULUAN}

Masa remaja adalah masa yang paling menyenangkan, karena masa remaja ini harus dilalui oleh seorang anak yang hendak menjadi dewasa. Anak akan mendapatkan pengalaman baru baik di lingkungan tempat tinggal dan lingkungan sekolahnya. Memiliki banyak teman bagi remaja adalah sesuatu yang membahagiakan karena degan memiliki banyak 
teman, remaja akan banyak mendapatkan berbagai pengalaman baru dan merasa keberadaan dirinya dihargai oleh orang-orang di sekitarnya.

Pada masa remaja banyak melibatkan suatu proses yang menjangkau suatu periode yang penting dalam kehidupan seseorang, menghadirkan begitu banyak tantangan dikarenakan begitu banyak perubahan yang harus dihadapi mulai dari perubahan fisik, biologis, psikologis dan juga sosial. pada masa remaja dalam perkembangannya memiliki suatu tugas berupa tugas perkembangan yang mesti dilalui sesuai dengan tahap perkembangannya. Santrock (2007) menyebutkan bahwa masa remaja memerlukan pertimbangan tentang usia dan pengaruh faktor sosial dan sejarah mendefinisikan remaja (Adolescence) sebagai masa perkembangan transisi antara masa anak dan masa dewasa yang mencakup perubahan biologis, kognitif dan sosial emosional.

Tantangan-tantangan dan tugas-tugas perkembangan tersebut akan menuntun pada proses-proses perubahan yang akan terjadi dalam diri anak remaja jika mampu dihadapinya secara adaptif dan dengan sukses. Namun pada kenyataanya tidak jarang remaja belum mampu mengatasi tantangan perubahan dan tugas-tugas perkembangan tersebut secara sukses, sehingga muncul berbagai konsekuensi baik secara psikologis dan emosional yang dapat merugikan diri remaja itu sendiri..

Remaja pada usia sekolah dalam hal ini siswa, cenderung menganggap hidup adalah penderitaan, tidak menyenangkan dan mereka cenderung berkehendak lari dari kehidupannya dengan cara-cara yang destruktif seperti: menyakiti diri, lari dari kehidupan dan keluarga, terlibat pergaulan bebas, pengguna alkohol, serta lebih jauh terlibat dalam dunia narkotika, psikotropika, obat-obatan terlarang dan zat adiktif lainnya. Mereka bingung karena pikiran dan emosinya berjuang untuk menemukan dirinya, memahami dan menyeleksi serta melaksanakan nilai-nilai yang ditemui dimasyarakat, disamping itu perasaan ingin bebas dari segala ikatanpun muncul dengan kuatnya.

Sebagai makhluk individu dan sosial, siswa akan menampilkan tingkah laku tertentu berdasarkan lingkungan dimana dia berada. Dalam proses interaksi tersebut akan terjadi peristiwa yang saling mempengaruhi antara individu yang satu dengan yang lain. Hasil dari peristiwa tersebut tentunya akan saling mempengaruhi sehingga akan menimbulkan perilaku sosial tertentu yang akan mewarnai pola interaksi tingkahlaku siswa. Seiring dengan adanya keinginan untuk mencoba hal-hal baru, dalam kehidupan sosial remaja di masyarakat seperti perilaku merokok yang dilakukan remaja tanpa adanya pemahaman mengenai bahaya dari merokok.

Bagi remaja yang merokok tentu membuatnya berisiko sangat serius bagi kesehatannya, hal ini dkarenakan remaja masih berada pada usia pertumbuhan baik pada tingkat fisik maupun emosionalnya. .Resiko merokok bagi kesehatan, para ahli mengungkapkan bahwa merokok bagi remaja jauh lebih buruk dibanding dengan orang dewasa yang merokok. Hersoni (2015) menyebutkan beberapa masalah yang bisa muncul jika remaja merokok yang bisa terlihat dari penampilannya, yaitu:

(1) Mengganggu performa di sekolah. Remaja yang merokok akan mengalami penurunan dalam nilai olahraganya karena tidak bisa berjalan jauh atau berlari cepat seperti sebelum merokok.Jika ikut ekstrakulikuler musik akan membuatnya tidak maksimal saat main musik, serta menurunkan kemampuan memori otaknya dalam belajar yang bisa mempengaruhi nilai-nilai pelajarannya. (2) Perkembangan paruparu terganggu. Tubuh berkembang pada tahap pertumbuhannya, dan jika seseorang merokok pada periode ini bisa mengganggu perkembangan paru-parunya.Terlebih jika remaja merokok setiap hari maka bisa membuatnya sesak napas, serta batuk yang terus menerus, dahak berlebihan dan lebih mudah terkena pilek berkali-kali.(3) Lebih sulit sembuh saat sakit. Ketika remaja sakit maka mereka akan lebih sulit baginya untuk bisa kembali sehat seperti semula karena rokok mempengaruhi sistem imun di dalam tubuh.Rokok ini juga memicu masalah jantung di usia muda serta mengurangi kekuatan tulang. (4) Kecanduan.

Remaja yang merokok cenderung jauh lebih mungkin menjadi kecanduan terhadap nikotin yang membuatnya lebih sulit untuk berhenti.Saat ia memutuskan untuk berhenti merokok, mka gejala penarikan seperti depresi, insomnia, mudah marah dan masalah mentalnya bisa berdampak negatif pada kinerja sekolah serta perilakunya. (5) Terlihat lebih tua dari usianya. Orang yang mulai merokok di usia muda akan mengalami proses penuaan lebih cepat, ia akan memiliki garis-garis di wajah serta kulit lebih kering sehingga penampilannya akan 
lebih tua dibanding usianya.Rokok juga membuat remaja memiliki jerawat atau masalah kulit lainnya, serta gigi yang kuning.

Selain itu bahaya merokok bagi pelajar diantaranya dapat meningkatkan resiko kanker paru-paru dan penyakit jantung di usia yang masih muda. Selain itu kesehatan kulit tiga kali lipat lebih beresiko terdapat keriput di sekitar mata dan mulut. Kulit akan menua sebelum waktunya atau biasa disebut penuaan dini. Jangan menganggap merokok bisa membantu menghilangkan stress saat ujian. Bukti medis menunjukkan bahwa merokok tidak menenangkan. Ini hanya efek sementara nikotin yang memberikan rasa tenang sesaat. Setelah itu jika sudah selesai merokok stress akan kembali lagi (Hersoni, 2015)

Menurut Murtiyani (2011) masa remaja merupakan masa yang rentan bagi seseorang untuk terlibat dalam prilaku menyimpang seperti rokok. Seorang remaja memilih untuk merokok erat kaitannya dengan belum matangnya mental seorang remaja. Seorang remajasudah tidak tidak lagi di katakan sebagai kanak-kanak, namun masih belim cukup matang untuk dikatakan dewasa sehingga masih sering gagal untuk memepertimbangkan dampak dari perilakunya sendiri. Pada saat bersamaan, seorang remaja untuk mencoba mencari pola hidup yang sesuai dengan keinginan dirinya, sehingga hal tersebut dapat berdampak negatik akibat perbuatannya maupun kepada orang lain sebagai dampak merokok. Sorang remaja tidak ragu untuk mencoba sesuatu yang dianggapnya baru meskipun hal tersebut berbahaya, karena diketahui bahwa remaja masih dalam kerangka mencari identitas diri yang sesungguhnya, sehingga dari status tersebut remaja dapat meningkatkan status social dirinya pada lingkungan sekitar.

Indonesia menduduki peringkat ke-4 jumlah perokok terbanyak di dunia yang tidak hanya terdiri dari orang dewasa namun juga remaja. Terdapat beberapa hal yang memengaruhi perilaku merokok pada remaja antara lain pola asuh orang tua, pengaruh teman sebaya, faktor kepribadian, dan juga pengaruh iklan (Sanjiwani dan Budisetyani, 2014). Kosumsi rokok di Indonesia mencapai 215 miliyar batang per tahunnya. Di Indonesia ada $60 \%$ perokok, $59 \%$ diantaranya adalah laki laki dan $37 \%$ nya perempuan (Hasbihtc, 2011). Angka kematian akibat rokok di negara berkembang meningkat hampir 4 kali lipat. Pada tahun 2000 jumlah kematian akibat rokok sebesar 2,1 juta dan pada tahun 2030 diperkirakan menjadi 6,4 juta jiwa. Sedangkan di negara maju kematian akibat rokok justru mengalami penurunan, yaitu dari 2,8 juta pada tahun 2000 menjadi 1,6 juta jiwa pada tahun 2030 (Aliansi Pengendalian Tembakau Indonesia, 2013).

Dari data di atas, masalah merokok merupakan masalah yang serius, mengingat merokok mempunyai dampak negatif baik pada perokok itu sendiri maupun orang disekitarnya yang tidak merokok (perokok pasif), setiap tahunnya jumlah perokok terus bertambah dan tingkat kematian akibat merokok setiap tahunnya terus meningkat. Hasil observasi, wawancara dan dokumentasi dari konselor pada SMP Palangkaraya diperoleh data beberapa siswa yang kedapatan membawa rokok di kantorng celana dan tas bukunya, di jok sepeda motor sewaktu dilakukan pemeriksaan mendadak oleh pihak sekolah. Terlihat pula beberapa siswa yang kepergok ketika merokok di belakang sekolah saat jam istirahat maupun saat pulang sekolah. Padahal perilaku merokok ini oleh pihak sekolah telah dilarang bahkan tercantum di tata tertib sekolah.

Fenomena tersebut, tentunya sangat merugikan siswa itu sendiri yang disebabkan kurangnya pemahaman mengenai bahaya merokok. Oleh karena itu para siswa perlu diberikan pengetahuan tentang bahaya merokok sehingga siswa benar-benar memahami dampak atau akibat dari merokok tersebut. Usaha yang dilakukan dapat melalui penyuluhan, pendidikan atau pembelajaran. Pendidikan adalah suatu usaha yang dilakukan dengan sengaja, teratur dan berencana dengan tujuan agar mampu mengembangkan perilaku yang diinginkan. Sekolah sebagai lembaga formal merupakan sarana dalam rangka mencapai tujuan pendidikan tersebut, siswa dapat belajar tentang berbagai pengetahuan..

Konselor sebagai salah satu pelaku utama dalam mengimplementasikan program pendidikan disekolah melalui layanan bimbingan dan konseling, memiliki peranan yang sangat strategis dalam mencapai tujuan pendidikan. Mengingat begitu pentingnya kehadiran konselor tersebut, diharapkan dapat membentuk karakter siswa yang baik sehingga mampu mengarahkan agar siswa bersikap dan berperilaku lebih positif. Karena itu, perlu disusun sebuah metode atau teknik yang tepat dalam upaya meningkatkan pemahaman siswa mengenai bahaya merokok. 
Salah satu media atau teknik layanan bimbingan dan konseling yang dapat diterapkan dalam upaya meningkatkan pemahaman siswa mengenai bahaya merokok yaitu dengan menggunakan teknik cynema therapy. Teknik cynema therapy merupakan salah satu media bimbingan dan konseling yang dapat diberikan kepada siswa dengan cara mempertontonkan film film, sehingga dapat memberikan inspirasi siswa yang pada akhirnya dapat meningkatkan pemahaman siswa terhadap bahaya merokok. Menurut Gary Solomon (Allen \& Krebs, 2007), Cynema therapy merupakan metode penggunaan film untuk memberi efek positip pada pasien. Profesor Psikologi di Community College of Southern Nevada ini menambahkan, masalah yang bisa diterapi adalah motivasi, hubungan, depresi, percaya diri, dan lain sebagainya. Tapi tidak termasuk gangguan kejiwaan yang akut.

Teknik cynema therapy terbukti efektif dalam mengintervensi dimensi psikologis. Hesley \& Hesley (2001) mengemukakan bahwa penggunaan film sebagai media terapi untuk membuka hambatan emosional pada individu ternyata efektif. Penelitian dari Robiah (2012), Nikmarijal (2012), Sapiana (2013), dan Muthiah (2013) disimpulkan bahwa teknik cynema therapy efektif mampu meningkatkan motivasi belajar siswa, mampu meningkatkan resiliensi siswa, dan dapat meningkatkan harga diri siswa. Milton Chen (2002) dalam penelitiannya menyebutkan bahwa anak-anak di Amerika menghabiskan waktu menonton televisi selama 4 jam sehari. Survey dari BKKBN bekerjasama dengan Lembaga Demografi Fakultas Ekonomi Universitas Indonesia (2009) menunjukan bahwa $87,5 \%$ remaja menyukai film.

Dari penjelasan di atas, maka dengan penerapan teknik cynema therapy diharapkan dapat efektif dalam mengintervensi dimensi psikologis siswa, termasuk dapat meningkatkan kemampuan siswa dalam memahami materi bahaya merokok, sehingga dengan demikian diharapkan siswa dapat memahami dan dalam praktiknya dapat menjauhi (tidak melakukan lagi) perbuatan merokok. Penelitian ini bertujuan untuk mengetahui apakah penerapan teknik cynema therapy efektif mampu meningkatkan pemahaman siswa terhadap bahaya merokok pada SMP Muhammadiyah Palangkaraya. Karena itu dengan teknik cynema therapy dapat menciptakan pembelajaran yang melatih kesiapan dan daya serap pemahaman peserta didik untuk tidak melakukan merokok, sehingga pengalaman dari pembelajaran yang diberikan benar-benar terarah, menarik dan bermakna. Dengan demikian hipotesis penelitian ini adalah bahwa dengan penerapan teknik cynema therapy efektif mampu dapat meningkatkan pemahaman siswa terhadap bahaya merokok pada SMP Muhammadiyah Palangkaraya.

\section{METODE}

Penelitian ini merupakan penelitian kuantitatif dengan menggunakan pendekatan eksperimen. Desain eksperimen yang digunakan di dalam penelitian ini adalah pre-experimental design dalam bentuk one group pretest-posttest design. Artinya dengan desain penelitian ini hanya menggunakan satu kelompok sebagai kelompok eksperimen yang diberikan perlakuan tanpa adanya kelompok pembanding. Populasi dalam penelitian ini yang dipilih erat hubungannya dengan masalah yang akan dipelajari (Effendi \& Tukiran, 2012). Populasi penelitian ini berjumlah 28 orang yang merupakan siswa kelas VIII-3 SMP Muhammadiyah Palangkaraya, dengan sampel 8 orang peserta didik yang terindikasi memiliki pemahaman pada materi bahaya merokok yang rendah. Penentuan sampel ini dipilih dengan menggunakan purposive sampling yaitu teknik penentuan sampel dengan pertimbangan tertentu (Sugiyono, 2008). Karena pemilihan sampel didasarkan pada ciri-ciri tertentu yang dinilai memiliki hubungan dengan ciri-ciri populasi yang diketahui sebelumnya. Pengumpulan data penelitian menggunakan wawancara, dokumentasi, angket dan focuss group discussion. Data yang diperoleh melalui angket dianalisis menggunakan uji statistik Paired Samples T Test dengan aplikasi software SPSS versi 17.00 .

\section{HASIL DAN PEMBAHASAN}

Data awal yang diperoleh sebelum intervensi dilakukan merupakan data pengukuran awal (pretest), digunakan untuk mengetahui pemahaman awal mengenai bahaya merokok, sehingga dapat diketahui kondisi awal subyek yang akan dijadikan sampel dalam penelitian ini. Dari hasil penyebaran angket sebagai langkah pengukuran awal (pretest) kemudian dianalisis menggunakan statistik deskriptif yaitu untuk mendeskripsikan data yang telah terkumpul. Setelah dilakukan penskoran, selanjutnya 
dilakukan menjumlahkan skor yang diperoleh oleh masing-masing siswa. Untuk mengetahui kondisi objektif tingkat pemahaman siswa terhadap bahaya merokok, maka digunakan kategorisasi dari Hadi (2004) sebagai berikut:

1) Mean ideal $+1,5 \mathrm{sd}$ ke atas = Tinggi

2) Mean ideal sampai dengan mean ideal $+1,5 \mathrm{sd}$ = Sedang

3) Mean ideal - 1,5 SD sampai dengan mean ideal $=$ Kurang

4) Mean ideal - 1,5 SD ke bawah = Rendah

Atas dasar ke-4 kategorisasi tersebut, selanjutnya dianalisis secara dekriptif kuantitatif dengan langkah-langkah sebagai berikut:

1) Menentukan rata-rata skor tertinggi dan terendah dari angket pemahaman bahaya merokok.

Skor tertinggi $=39 \times 4=156$
Skor terendah $=39 \times 1=39$

2) Menentukan rata-rata skor ideal (mean ideal) :

$1 / 2$ (skor tertinggi + skor terendah)

$1 / 2$ (skor tertinggi + skor terendah)

$1 / 2(156+39)=97,5$ dibulaktan 98

3) Menghitung standar deviasi (SD): 1/6 (skor

tertinggi - skor terendah)

$1 / 6$ (skor tertinggi - skor terendah)

$1 / 6(156-39)=19,5$ dibulatkan 20

Berikut ini terdapat 8 siswa yang di kategorikan kurang dalam memahami bahaya merokok, sedangkan hasil perbandingan hasil pretest dan posttest berdasarkan dari penyebaran angket pemahaman siswa tentang bahaya merokok yang telah disebarkan ke subyek penelitian secara sederhana dapat dilihat pada tabel 1 berikut:

Tabel 1 Hasil Analisis pretest dan posttest pemahaman siswa terhadap bahaya merokok

\begin{tabular}{llccrl}
\hline No & Nama siswa & $\begin{array}{c}\text { Hasil pretest } \\
(\mathbf{0 1})\end{array}$ & $\begin{array}{c}\text { Hasil posttest } \\
(\mathbf{0 2})\end{array}$ & $\begin{array}{c}\text { Hasil } \\
(\mathbf{0 2 - 0 1})\end{array}$ & Keterangan \\
\hline 1. & Sen & 97 & 133 & 36 & Meningkat \\
\hline 2. & Sel & 94 & 131 & 37 & Meningkat \\
\hline 3. & Rab & 95 & 126 & 31 & Meningkat \\
\hline 4. & Kam & 88 & 119 & 21 & Meningkat \\
\hline 5. & Jum & 97 & 135 & 38 & Meningkat \\
\hline 6. & Sab & 85 & 120 & 35 & Meningkat \\
\hline 7. & Ah & 88 & 126 & 38 & Meningkat \\
\hline 8 & Sene & 92 & 111 & 19 & Meningkat \\
\hline & Rata-rata & 92 & 125.125 & & \\
\hline
\end{tabular}

Kemudian dari data hasil pretest dan posttest selanjutnya dibandingkan hasilnya untuk mengetahui dan menguji hipotesis yang telah ditentukan sebelumnya. Pengujian ini mengunakan uji tanda untuk mengetahui hasil perbedaan antara sebelum dengan sesudah diberikan perlakuan yaitu berupa pemberian cynema therapy tentang pemahaman siswa terhadap bahaya merokok..

Adapun pelaksanaan posttes setelah pemberian intervensi sebagaimana dipaparkan pada tabel 1 di atas bahwa perbedaan nilai dari pretes ke posttes menunjukkan adanya peningkatan dalam pemahaman siswa tentang bahaya merokok. Hasil posttes menunjukkan bahwa nilai lebih tinggi dari nilai pretest, maka dapat diartikan bahwa setelah pemberian treatment dengan teknik cynema therapy kepada 8 siswa tersebut menunjukkan peningkatan.

Peningkatan tersebut menunjukkan bahwa teknik cynema therapy dapat meningkatkan pemahaman siswa tentang bahaya merokok. Berdasarkan data pada tabel 1 di atas kemuadian dibuat gambar untuk memperjelas data yang sudah dipaparkan sebagai berikut: 


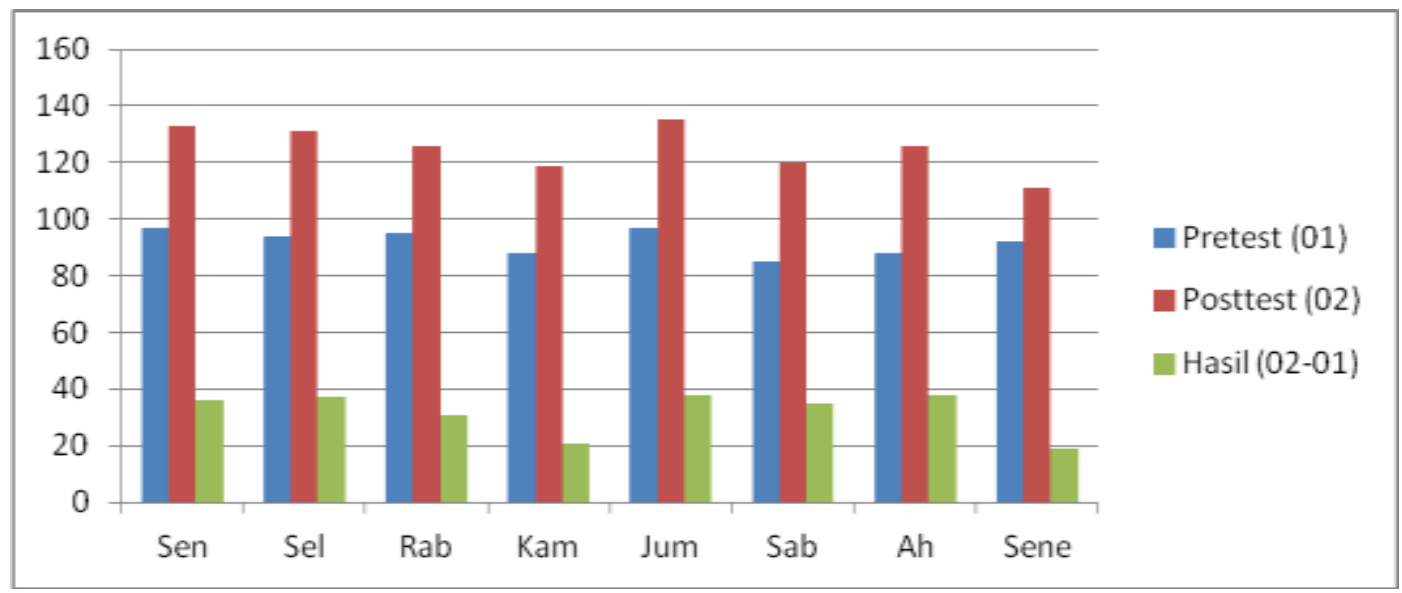

Gambar 1: Hasil pretets dan posttest pemahaman siswa terhadap bahaya merokok

Berikut dijelaskan masing-masing subyek penelitian berdasarkan data pada tabel 1 dan gambar 1, yaitu:

\section{Suyek SEN}

Subyek SEN menunjukkan skor nilai pada saat pretest 97 pada kategori kurang dalam memahami bahaya merokok, namun setelah diberikan perlakuan menunjukkan adanya peningkatan skor nilai pada kuesioner saat posttes 133. Adanya peningkatan skor tersebut menggambarkan bahwa pemahaman siswa mengenai bahaya merokok meningkat setelah mengikuti perlakuan (treatmen) yang ditunjukkan dengan selisih nilai 36 point.

2. Subyek SEL

Skor yang diperoleh subyek SEL menunjukkan nilai pretest 94 di kategorikan bahwa pengetahuan mengenai bahaya rokok kurang, namun setelah diberikan perlakuan menunjukkan ada peningkatan skor nilai pada saat posttes 131. Peningkatan skor tersebut menggambarkan bahwa pemahaman siswa terhadap bahaya merokok meningkat setelah mengikuti treatmet atau perlakuan dengan selisih nilai 37 point.

3. Subyek RAB.

Nilai yang diperoleh subyek RAB pada saat pretest memperoleh skor 95 dengan kategori kurang, setelah dilakukan treatment menunjukkan adanya peningkatan skor nilai pada saat posttes 126 . Adanya peningkatan skor tersebut menunjukkan bahwa pemahaman siswa mengenai bahaya merokok meningkat selisih nilai 31 point.

\section{Subyek KAM}

Setelah mengikuti pretest, nilai yang diperoleh subyek KAM menunjukkan skor 88 berada pada kategori kurang, setelah diberikan layanan atau perlakuan menunjukkan peningkatan bahwa nilai subyek KAM pada saat posttes dengan skor 119. Dengan adanya peningkatan skor tersebut menggambarkan bahwa pemahaman siswa terhadap bahaya merokok meningkat yang ditunjukkan dengan selisih nilai 21 pont.

5. Subyek JUM

Setelah mengikuti prestest, nilai subyek JUM menunjukkan skor 97 yang berada kategori kurang dalam memahami bahaya rokok, namun ketika telah diberikan perlakuan menunjukkan bahwa nila subyek JUM ada pada skor nilai posttes 135 . Terjadinya peningkatan skor pada diri JUM menunjukkan bahwa pemahamannya mengenai bahaya merokok meningkat setelah mengikuti treatmet dengan selisih nilai 38 point.

6. Subyek SAB

Nilai subyek SAB setelah mengikuti pretest menunjukkan skor 85 ada pada kategori kurang dalam memahami bahaya merokok, namun setelah diberikan perlakuan menunjukkan adanya peningkatan skor nilai pada saat posttes 120 . Ini berarti bahwa ada peningkatan pemahaman pada diri siswa mengenai bahaya merokok, selisih nilai 35 point.

7. Subyek AH

Skor nilai yang diperoleh subyek AH pada saat pretest 88 berada pada kategori kurang ini berarti bahwa pengetahuan mengenai bahaya rokok sedang, setelah dilakukan pemberian layanan atau perlakuan menunjukkan peningkatan skor nilai pada saat posttes 126 . Adanya peningkatan skor tersebut menunjukkan pada pemahaman 
siswa mengenai bahaya merokok meningkat dengan selisih nilai 38 point.

8. Subyek SENE

Ni yang diperoleh subyek SENE pada saat pretest dengan skor 92 berada pada kategori bahwa pengetahuan mengenai bahaya rokok bagi SENE kurang, setelah diberikan perlakuan menunjukkan adanya peningkatan dengan skor nilai pada saat posttes 111. Ini berarti pemahaman SENE terhadap bahaya merokok menunjukkan ada peningkatan dengan selisih nilai 19 point.

Adapun hasil uji keefektifan penerapan teknik cinema therapy untuk meningkatkan pemahaman siswa akan bahaya merokok dianalisis dengan statistik non-parametrik tes melalui uji statistik Paired Samples T Test Sedangkan hipotesis dalam penelitian ini yaitu: Ha : "Penerapan teknik cynema therapy dapat meningkatkan pemahaman siswa terhadap bahaya merokok pada SMP Muhammadiyah Palangkaraya".

Ho : "Penerapan teknik cynema therapy tidak dapat meningkatkan pemahaman siswa

terhadap bahaya merokok pada SMP Muhammadiyah Palangkaraya".

P

a

r

a

$\mathrm{m}$

e

$\mathrm{t}$

e

r

u

$\mathrm{j}$

i

Jika $\quad \mathrm{t}$ tabel $\geq \mathrm{t}$ hitung maka Ho diterima, dan $\mathrm{Ha}$ di tolak

Jika $\mathrm{t}$ tabel $<\mathrm{t}$ hitung maka Ho ditolak, dan $\mathrm{Ha}$ diterima

Perhitungan dilakukan dengan menggunakan SPSS 17.00. Hasil dari perhitungan disajikan pada tabel 2 sebagai berikut:

Tebel 2 Paired Samples Statistics

\begin{tabular}{|c|c|c|c|c|c|c|}
\hline & & Mean & $\mathrm{N}$ & & Std. Deviation & $\begin{array}{l}\text { Std. Error } \\
\text { Mean }\end{array}$ \\
\hline \multirow[t]{2}{*}{ Pair 1} & Pretest & 92.0000 & & 8 & 4.53557 & 1.60357 \\
\hline & Posttest & 125.1250 & & 8 & 8.09652 & 2.86255 \\
\hline
\end{tabular}

Berdasarkan hasil analisis uji statistik Paired Samples $T$ Test dengan menggunakan SPSS 17.00 for windows diketahui bahwa pemahaman siswa terhadap bahaya merokok mengalami peningkatan dari rata-rata awal 92.0000 menjadi 125.1250 dengan jumlah rata-rata peningkatan sebesar 33.125. Dengan demikian berdasarkan hasil uji hipotesis yang telah dilakukan, disimpulkan bahwa penerapan teknik cynema therapy efektif dapat meningkatkan pemahaman siswa terhadap bahaya merokok pada SMP Muhammadiyah Palangkaraya. Hal ini diperkuat dengan uji statistik yang telah dilakukan. Ini menegaskan bahwa dengan teknik cynema therapy ternyata efektif dalam meningkatkan pemahaman siswa terhadap bahaya merokok pada SMP Muhammadiyah Palangkaraya..
Setelah dilakukan penelitian, ternyata dari hasil analisis data berupa uji efektivitas disimpulkan bahwa terdapat peningkatan pemahaman terhadap bahaya merokok setelah diberikan perlakuan atau treatment dengan cynema therapy pada siswa, hal ini terlihat dari perbedaan antara sebelum perlakuan (pretest) dan sesudah perlakuan (posttest).

Teknik cynema therapy merupakan salah satu media bimbingan konseling dengan menayangkan atau memperlihatkan berbagai film yang dapat menginspirasi siswa dan dianggap sebagai solusi yang akhirnya dapat meningkatkan pemahaman terhadap bahaya merokok. Berg-Cross, Jennings \& Barunch (1990) menyatakan cinema therapy adalah teknik terapeutik khusus yang menggunakan film komersial yang dipilih untuk mendapatkan arti 
terapeutik pada klien tentang pandangan terhadap individu atau terhadap orang lain. Cynema therapy membuat kekuatan itu sebagai alat untuk meningkatkan kesadaran. Melalui cinematherapy, konseli akan belajar dalam mencari dan menemukan suatu wawasan baru dalam memandang fenomena sosial yang terjadi di lingkungan sekitarnya (Niva, 2016).

Merokok merupakan salah satu fenomena merokok. Merokok merupakan kebiasaan negatif yang dilakukan oleh seseorang terutama bagi siswa. Perilaku merokok bagi sebagian remaja merupakan hal sulit untuk dihindari, hal tersebut sebagai dari suatu bentuk kelainan dalam proses interaksi sosial. Erikson (Komasari \& Fadilla, 2000) mensinyalir keterkaitan dengan adanya krisis aspek psikososial yang dialami pada masa perkembangannya yaitu masa ketika mencari jati diri. Dalam masa ini dalam perkembangannya sering terjadi ketidaksesuaian antara perkembangan psikis dan perkembangan sosial.

Upaya-upaya yang dilakukan untuk menemukan jati diri oleh siswa atau remaja tersebut tidak selalu berjalan dengan baik sesuai harapan masyarakat, sehingga beberapa remaja melakukan perilaku merokok sebagai cara pelampiasan, sehingga merokok bagi sebagian remaja merupakan perilaku proyeksi dari rasa sakit baik psikis maupun fisik, walaupun di sisi lain merokok pada saat pertama kalinya dirasakan tidak mengenakkan. Helmi (2010) mengungkapkan bahwa saat pertama kali mengkonsumsi rokok, kebanyakan remaja mungkin mengalami gejala-gejala batuk, lidah terasa getir, dan perut mual bahkan mereka mengetahui bahaya dari merokok itu sendiri. Namun demikian, sebagian dari para pemula tersebut mengabaikan dan melanggar pengalaman, perasaan dan segala bahaya yang mereka ketahui tersebut.

Silvan Tomkins menyebutkan ada 4 tipe perilaku merokok berdasarkan Management Of Effect Theory sebagai berikut: 1) Tipe perokok yang dipengaruhi oleh perasaan positif. Dengan merokok, seseorang merasakan penambahan rasa yang positif. 2) Perilaku merokok yang dipengaruhi oleh perasaan yang negatif. Banyak orang yang menggunakan rokok untuk mengurangi perasaan negatif, misalnya bila ia marah, cemas, gelisah, rokok dianggap sebagai penyelamat. 3) Perilaku merokok yang adiktif. Green (Enung, 2006) menyebutnya sebagai psychological Addiction Mereka yang sudah adiksi akan menambah dosis rokok yang digunakan setiap saat setelah efek dari rokok yang digunakan berkurang. 4) Perilaku merokok yang sudah menjadi kebiasaan. Mereka yang menggunakan rokok bukan karena untuk mengendalikan perasaan, tetapi karena benarbenar sudah menjadi kebiasaan rutin (Enung, 2006).

Penelitian Waters, dkk. (2006) menunjukkan bahwa $70 \%$ dari 351 saat ini (masa 30 hari) perokok dilaporkan merokok sosial. Tidak ada perbedaan signifikan yang ditemukan dalam motivasi untuk berhenti antara kelompok merokok. Namun, perbedaan signifikan yang ditemukan antara kepercayaan kelompok untuk berhenti, jumlah hari merokok, dan jumlah rokok yang dihisap pada setiap hari. perokok sosial lebih dari yang diharapkan tidak menganggap diri mereka sebagai perokok. Analisis regresi logistik menunjukkan bahwa ketergantungan fisik dan psikologis yang lebih rendah dan skor dukungan sosial yang lebih tinggi diprediksi merokok sosial.

Sedangkan Murphy-Hoefer, dkk. (2004) dalam penelitiannya menyebutkan bahwa Perokok setengah lebih mungkin sebagai perokok percaya bahwa ada risiko kesehatan dari merokok hanya pada akhir pekan atau beberapa hari seminggu. Pesan anti tembakau untuk perokok dewasa muda perlu berkomunikasi lebih efektif konsep bahwa setiap batang rokok yang mereka merokok adalah melakukan perusakan.

Pemahaman terhadap bahaya merokok sangat diperlukan bagi diri siswa khususnya dalam proses pemahaman ini siswa tidak hanya sebatas mengenal tetapi juga siswa harus dapat menghubungkan akan dampak bahaya rokok bagi dirinya. Dengan demikian diharapkan mereka dapat menghentikan kebiasaan merokok dan bila perlu menghindari rokok bagi yang belum pernah mengkonsumsinya. Penelitian Puryanto dan Sayono (2012), Tumigolung (2013), Nuradita dan Maryam (2013) dan Ikhsan (2013) menyimpulkan bahwa terdapat pengaruh yang signifikan bagi siswa yang telah mendapat pendidikan atau pelatihan tentang pemahamannya terhadap bahaya merokok, sehingga tingkat pengetahuan mereka meningkat, hal ini terbukti dapat mengurangi konsumsi rokok pada remaja.

Hasil penelitian di atas, menunjukkan bahwa untuk mengurangi akan bahaya merokok di kalangan remaja, salah satunya dengan dilakukannya pendidikan atau pelatihan dengan menggunakan teknik cynema therapy yang diberikan. Penelitian Smithikrai, Longthong, \& 
Peijsel (2015) ditemukan bahwa film mampu meningkatkan kompetensi sosial individu. Disamping itu sinema berupa film mampu menjadi alat yang kuat untuk meningkatkan karakteristik positif dan mengurangi karakter negatif. Dari film itu sendiri dapat menceritakan wilayah yang ingin diketahui, sehingga hasilnya dapat dicapai oleh individu agar hidupnya berkualitas dan mampu dihubungkan ke dalam dirinya hingga akhirnya menghasilkan perasaan yang lebih baik, termotivasi untuk berperilaku hidup sehat dan mampu menepatkan diri sebagai pribadi yang berguna bagi masyarakat lingkungannya.

\section{SIMPULAN DAN SARAN}

Penelitian ini dilakukan untuk menguji penerapan teknik cynema therapy untuk meningkatkan pemahaman siswa terhadap bahaya merokok pada SMP Muhammadiyah Palangkaraya. Berdasarkan hasil pre-test diperoleh 8 siswa yang dipilih sebagai subyek penelitian. Hasil penelitian menunjukkan bahwa penerapan teknik cynema therapy dapat meningkatkan pemahaman siswa terhadap bahaya merokok pada SMP Muhammadiyah Palangkaraya. Kesimpulan ini berdasarkan dari hasil analisis uji statistik Paired Samples $T$ Test dengan menggunakan SPSS 17.00 for windows diketahui bahwa terdapat perbedaan yang signifikan nilai rata-rata setelah perlakuan yang lebih tinggi dari pada sebelum diberikan perlakuan. Dengan demikian teknik cynema therapy ternyata efektif mampu dalam meningkatkan pemahaman siswa terhadap bahaya merokok pada SMP Muhammadiyah Palangkaraya.

$$
\text { Selanjutnya,disarankan sebagai }
$$

berikut: (1) penerapan teknik cynema therapy sebagai teknik konseling perlu dilakukan oleh konselor dalam pemberian pelayanan konseling sesuai dengan permasalahan yang dihadapi siswa, sehingga konselor harus mampu menganalisis makna yang tersirat dalam film tersebut sebagai wahana terapeutik. (2) dalam pelaksaannya membutuhkan sarana dan prasarana yang memadai ketika konselor melaksanakan kegiatan layanan bimbingan dan konseling dengan menggunakan teknik cynema therapy dan atau teknik lainya yang sejenis. (3) untuk peneliti selanjutannya, perlu dilakukan pengembangan teknik cynema therapy pada bidang lainnya dengan karakteristik siswa yang beragam, sehingga penelitian ini lebih menggeneralisasi dan representatif.

\section{DAFTAR RUJUKAN}

Aliansi Pengendalian Tembakau Indonesia. (2013). Peta Jalan Pengendalian Produk Tembakau Indonesia. Surakarta: Muhammadiyah University Press.

Berg-Cross, L., Jennings, P., \& Barunch, R. (1990). Cinematherapy: Theory and Application. Psychotherapy in Private Practice, 8 (1), 135 - 156.

Enung, F. (2006). Psikologi perkembangan. Bandung: Pustaka Setia.

Hadi, S. (2004). Metodologi

Research.Yogyakarta:

Andi Ofset.

Helmi. (2010). Perasaan saat memegang rokok. Diakses 11 Juni 2016.

https://fajarjuliansyah.wordpress.com./ 7/2/2010/perasaan.saat.memegang.rok ok.

Hersoni, S. (2015). Bahaya Merokok Untuk Usia Remaja Pasca Sarjana Keperawatan, Cimahi: STIKes Jenderal Achmad Yani. Diakses 26 Juli 2016.

http://www.stikes-bth.ac.id/berita-

185_bahaya-merokok-untuk-usia-remaja-.html.

Hesley , J.W. \& Hesley, J. G. (2001). Rent Two Films and Let's Talk in the Morning: Using Popular Movies in Psychotherapy (2nd ) NY: Wiley and Sons

Ikhsan, H. (2013). Pengaruh Pendidikan Kesehatan Bahaya Merokok terhadap Perilaku Mengurangi Konsumsi Rokok pada Remaja. Jurnal Ilmu Keperawatan dan Kebidanan, 2 (1). Diakses 26 Mei 2016. http://www.ejurnal.com/2013/10/pengaruhpendidikan-kesehatan-bahaya.html.

Komalasari, D. dan Helmi, A.F. (2000). FaktorFaktor Penyebab Perilaku Merokok Pada Remaja. Jurnal Psikologi. Vol. 9 No. 2. Yogyakarta: Universitas Gadjah Mada. 
Komalasari \& Fadilla. (2000). Faktor-Faktor Penyebab Perilaku Merokok Pada Remaja. Jurnal kesehatan. ISSN 0215 8884.

Murphy-Hoefer, R. Alder, S. and Cheryl H. C. (2004). Perceptions about cigarette smoking and risks among college students. Oxford Journals Medicine \& Health, Nicotine \& Tobacco Research, Volume 6, Issue Suppl 3 Pp. S371S374.

Murtiyani, N. (2011). Hubungan Pola Asuh Orang Tua dengan Kenakalan Remaja di RW V Kelurahan Sidokare Kecamatann Sidoarjo. Jurnal Keperawatan, 01(01), 1-9.

Muthi'ah, A. (2013). Keefektifan Cinema Therapy Untuk Meningkatkan Resiliensi Peserta didik SMP kelas Akselerasi. Jurusan Bimbingan Konseling. FIP Universitas Negeri Malang.

Nikmarijal. (2012). Peningkatan Self-Esteem Dengan Layanan Informasi Bermuatan Cinematherapy. Thesis. Universitas Negeri Padang.

Niva, H. (2016). Penerapan Pendekatan Cinematherapy Untuk Meningkatkan Prilaku Prososial Pada Siswa Bosowa International School Makasar. Jurnal Psikologi Pendidikan \& Konseling. Vol. 2 No. 1 Juni 2016. Hal 41-48.

Nuradita dan Mariyam. (2013). Pengaruh Pendidikan Kesehatan terhadap Pengetahuan tentang Bahaya Rokok pada Remaja di SMP Negeri 3 Kendal. Jurnal Keperawatan Anak. 1 (1):4448.

Puryanto, Santoso, E.J. dan Sayono. (2012). Pengaruh Pendidikan Kesehatan terhadap Pengetahuan dan Sikap Siswa tentang Bahaya Merokok. Jurnal Keperawatan, 01(01), 1-9.

Rob A. and Nina K. (2007). Dramatic Psichological Storytelling Using the Expressive Arts and Psychotheatrics. Palgrave Macmillan: Martin's Press.
Sanjiwani, N. L. P. Y. dan Budisetyani, I G. A. P. W. (2014). Pola Asuh Permisif Ibu dan Perilaku Merokok Pada Remaja Laki-Laki di Sma Negeri 1 Semarapura, Jurnal Psikologi Udayana, 2014, Vol. 1, No. 2, 344-352

Santrock, J. W. (2007). Adolescence. $11^{\text {th }}$ ed. New York: McGrow-Hill.

Sapiana. (2014). Pengaruh Bimbingan Kelompok Teknik Cinema therapy Terhadap Motivasi Belajar Siswa Kelas X Multimedia Di SMK Negeri 1 Limboto Kabupaten Gorontalo. Other Thesis, Universitas Negri Gorontalo. (online). Diakses tanggal 21 Mei 2016. http://eprints.ung.ac.id/2358/2/2013-186201111409055-bab125072013074842. pdf.

Smithikrai, C. Longthong, N. \& Peijsel, C. (2015). Effect of Using Movies to Enhance Personal Responsibility of University Students. Asian Social Science, 15, (5), 1 - 9 .

Sugiyono. (2008). Metode Penelitian Pendidikan Pendekatan Kuantitatif, Kualitatif, dan R\&D, Bandung: Alfabeta.

Tumigolung, H.C.S. (2013). Pengaruh Pendidikan Kesehatan terhadap Tingkat Pengetahuan Siswa tentang Bahayam Merokok di SMA Negeri 1 Manado. Jurnal Keperawatan UNSRAT, 1 (1). Diakses 26 Juli 2016. http://ejournal.unsrat.ac.id/index.php/jk $\mathrm{p} /$ article/ view/2186.

Waters, K. Harris, K. Hall, S. N.MD. N. Waigandt, A. (2006). Characteristics of Social Smoking Among College Students. Published in final edited form as: J Am Coll Health. 2006 Nov-Dec; 55(3): 133-139. doi: 10.3200/JACH.55.3.133-139 PMCID: PMC2963439 NIHMSID:NIHMS 9227. 